Book Review

\title{
An Introduction to Islamic Economics
}

By Muhammad Akram Khan. Islamabad, International Institute of Islamic Thought and Institute of Policy Studies, Pakistan, 1994, xii + 153 pp.

It is perhaps desirable to preface the review of a book with a brief description of its form and content, more so in the area of Islamic economics, where formal writing structures have yet to evolve and much diverse material tends to be treated under similar, even misleading, titles. Akram's book opens with an enudite foreword by Khurshid Ahmad. The text contains six chapters of uneven length spread over 111 pages. Two appendices, notes and references, a select bibliography to help further research, and a couple of indexes constitute its remaining portion.

The Introduction is a neat, petite work. Simple language, a lucid style, an uncompromising stance, and reliance on original sources are some of its notable features. It has not a few seminal ideas and some outlandish ones as well. The vast coverage inevitably is at some expense of depth and detail.

Chapter 1 provides a broad picture of Islamic economics for those who may not have the time to read the entire book (p. xii). It is a potpourri of ideas concerning such varied topics as the Islamic worldview, basic assumptions of the discipline, economic organization, the role of money, the problem of poverty, fiscal management, and the sharing of knowledge. Understandably, positions are taken without much argument to support them. 
Chapter 4, on Islamic economics in practice, disposes of such vast areas as Islamic banking, zakah, insurance, awqäf, and hisbah in just five pages! Chapter 6 deals, in an even smaller space, with the "directions of future research," selecting a holistic approach, the search for interest-free international economic order, technology, and economic power structures as priority areas. The remaining three chapters make some real contribution to the literature and provide justification for reviewing the book.

Chapter 2, on the nature of Islamic economics, traces the recent upsurge in writings on inadequacy of mainstream economics to resolve the perplexing problems of inequity, unemployment, and poverty faced by the majority of the people in the world today. According to Akram, the failure is due to the discipline having a narrow materialistic base, unrealistic assumptions, and a colonial legacy of exploitation that is still operative against the weak. The nonperformance of mainstream economics on crucial fronts, plus the recent collapse of the socialist alternative in the former Soviet Union and Eastern Europe, leaves a vacuum that many Muslim scholars, including Akram, think Islamic economics, bestowed with divine wisdom, alone is qualified to fill. But what is Islamic economics and what makes it superior to its mainstream counterpart?

Not many have attempted to provide a precise definition of Islamic economics. Those who have, seldom depart from the mainstream scarcity orientation, beyond linking their formulations to the notion of faläh, an epitome of the Islamic view of welfare. Akram ventures a break when he says that "Islamic economics aims at the study of human faläh achieved by organizing the resources of the earth on the basis of cooperation and participation" (p. 33). The statement does not take note of scarcity, even implicitly, for reasons we shall see later. The definition is followed by an insightful explanation of its key elements: falāh, resources, cooperation, and participation.

Following Rāghib al-Isfahānī, Akram treats falāh as a unitary concept stating its main elements in the life here and in the hereafter, as also the linkage between the two. He presents these elements in Table 2 , both for the micro and macro levels and then classifies them broadly into those that are needed, respectively, for survival, freedom from impoverishment, and for ensuring a dignified existence. Thus, fulfillment of the basic needs, investment to accelerate growth, and enhancement of power-economic and military-lie, inter alia, at the heart of the concept.

But faläh cannot be achieved unless certain conditions-spiritual, cultural, political, and economic - are met. The cultural requirements include establishment of a system for prayers, pursuit of knowledge, avoidance of gambling and intoxicants, supporting "right" and opposing "wrong," and proper use of resources. Among the economic conditions are infäq (spending in the way of God), the prohibition of interest ( $r i b \bar{a})$, the fulfillment of covenants and trusts, the enforcement of justice, the encouragement of enterprise, and the concern for the environment. Of course, paramount is 
the political commitment to enforce the various requirements of the Shari'ah, including readiness for jihad (striving in the cause of God).

"In brief," Akram concludes, "faläh is a multi-dimensional concept. It covers the whole life of an individual and all aspects of a society. Its different conditions reinforce and supplement each other. Establishing a socio-economic institutional framework facilitates its achievement. The role of the government can also be very important in promoting faläh of the people" (p. 43). Perhaps one has yet to come across a better description of this important concept in Islamic economics.

However, in his discussion of resources, Akram's position on the issue of their scarcity seems a little puzzling. Since some other writers also share this position, a hurried look at it may not be out of place. The Qur'an informs us that God has stocked the Earth (and heavens) with inexhaustible treasures to provide sustenance for all His creatures. But to draw from this, as Akram and others do, the inference that scarcity becomes nonexistent for economics, whether secular or Islamic, is rather eristic, to put it mildly. The catch is in the failure to realize that the fact of the existence of ample resources for human beings and others at all points in time and space is one thing, while their availability to individual or groups at a given hour and location and in the required quantities is quite another. It is not the existence of resources per se, but the state of their availability that lends meaning to the idea of scarcity as a cornerstone of economics. The availability of resources is an increasing function of knowledge-knowledge of their existence, of the ways to extract or obtain them, of their uses, and of their costs. The history of the march of human civilization is the history of human conquest of nature. It is the history, in essence, of pushing outward relentlessly the frontiers of scarcity through unceasing inventions and innovations in science, technology, and societal management.

Scarcity, as explained above, is a part of the divine scheme to spur humanity into action and to test people thereby, for the Qur'an not only talks of God's bountiful resources but also informs us that He alone is the source of knowledge and that $\mathrm{He}$ gives it to those who seek only bit by bit, lest they become proud and arrogant. The proposition that scarcity of resources is just a human-made phenomenon must be taken with a grain of salt. Improper use of resources or their maldistribution may be aggravating factors, but they are not the essence of scarcity. To regard scarcity as a mere disturbance factor in the "natural state of adequacy" of resources (p. 45) is neither correct nor necessary. In any case, to define such a state precisely is very difficult, if not impossible. Thus, resources remain limited because of the inadequacy of human knowledge despite God's benevolence. Presumably, one may visualize Islamic economics as a study of human behavior concerning the use of scarce resources for satisfying multifarious wants in such a way as would maximize faläh.

In the closing part, the chapter enumerates the "sources of Islamic economics" and shows that it is superior to mainstream economics in its approach, which is interdisciplinary, has both normative and positive 
aspects, and can use tools for analysis developed by the latter. But Akram seems unreceptive to the idea of indulging in a critical evaluation of mainstream economics with a view to integrating its unobjectionable and useful propositions with revealed knowledge in a quest for Islamization of the discipline (pp. 54-55). This provides a linkage with chapter 3 , which deals with the methodology of Islamic economics and where Akram seems to relax his stance on the point (p. 63). In that chapter, Akram discusses, in broad and general terms, the methodology of Islamic economics and seeks to show how it differs from that of mainstream economics. Some related issues, such as the Islamic approach to mainstream economics, the roles of revelation and reason, and the assumption of an ideal Islamic society are also touched upon (p. 57).

Unlike secular economics, reason cannot be independent of faith and morality in an Islamic dispensation. Since the core of Islamic economicsthe Qur'an and the Sunnah-provides guidance, says Akram, on a small number of questions, a dominant part of economic reality requires the application of human reason and intellect, but within the divine framework (p. 63). No Islamic economist will dispute this position, but some of Akram's observations, such as on the role of assumptions and model construction, may attract attention.

Akram states that the Shari'ah supports the use of inductive reasoning in the field of Islamic economics. Indeed, he endorses the view that Muslims have made significant contributions to the development of the method (p. 64). But building a model on the basis of deductive logic is not acceptable to him, as "model-building involves a series of deductions from initial premises which assume perfect knowledge of the future-an assumption which the Islamic economist tends to reject" (p. 65). One may find it difficult to accept this view both as a point of fact and logic. The fact is that the bulk of argumentation in writings on Islamic economics continues to rely on a priori reasoning, if only because we do not yet have any model of an economy operating according to Islamic norms to provide the needed data for constructing or testing our theories. The use of real-life data from current Muslim economies to erect and verify Islamic postulates, as Akram seems to suggest (p. 106), may prove more perilous than rewarding.

Furthermore, it is difficult to read a religious import into an assumption, as the latter is hardly a matter of faith or fact. Assumptions should be seen as no more than devices to simplify complex situations in order to isolate relevant variables to study relationships for, unlike in natural sciences, the facility of controlled experimentation is not available in social disciplines. It is interesting that, only a few pages later, one finds Akram diluting his position, stating: "Islamic economics treats the future outcome as known" (p. 69). He adds further, "Its future outcome is the objective of achieving falah." But the objective and the outcome of an effort, whether economic or non-economic, can be identical without fail only in the absence of uncertainty, i.e., with perfect knowledge about the future! 
Methodological issues are difficult terrain. There has been a notable resurgence of writings in the area during the past two decades, characterized with a distinct trend of philosophy and economics getting closer. Methodology is a much wider subject than the discussion on methods. Furthermore, in a scientific research program, the issue is no longer the preference of one method over the others. Rather, the problem is of their judicious use in support of one another depending on the nature and the stage of inquiry. Islamic economics still awaits a scholarly discussion on methodological questions.

Akram is realistic when he says that "most of the literature on Islamic economics assumes an ideal Islamic society which does not exist anywhere and the possibility of its coming into being in the near future is also remote" (p. 73). But ironically, his own Introduction seems oblivious to this fact. All through his work, he juxtaposes the realities of the existent capitalist societies with the ideals of a nonoperating Islamic model to claim superiority for the latter without the slightest realization that he is comparing, unwittingly, apples with oranges. The lapse detracts seriously from the academic value of his work. Nevertheless, Akram's advice that to present an analysis of the application of the Islamic principles in present-day society should be the main occupation of Muslim economists is quite expedient. It would generate, as he believes, a theory of transition that is missing in the literature and may make others interested in taking a closer look at the Islamic economic system (p. 77).

Chapter 5 sees "hope for the future" in the potential of Islamic economics to relieve the world of its many intractable problems, such as the coexistence of unemployment and inflation, poverty amid plenty, increasing income disparities within and among nations, and reckless spending by the state that conventional economics has failed to resolve. Islamic economics is expected to do so through a new development concept and strategies, including a fresh approach to the issues of investment criteria, planning strategy, foreign aid, choice of technology, economic power, consumers' sovereignty, and the role of public policy. The primary source of elation here or elsewhere in the Introduction essentially is the faith in the magic wand of the abolition of interest, the institution to which the book attributes almost any and every ill of the capitalist economy, including environmental degradation!

Clearly, this brief review cannot do justice to all the ideas that Akram presents. Still, it is efficacious to point out that eyebrows may be rasied on not a few of them, like treating zakah as a tax (p. 23), the inadmissibility of limited liability for shareholders in modern corporations (Appendix 1), the abolition of interest implying the availability of funds "free of cost" in an Islamic system (p. xi), the raising of interest rates during inflation only fuelling inflation (p. 13), and deficit financing being invariably undesirable (p. 23). Presumably, to clinch such issues required more explanation and argument than the Introduction provides. 
Taken as a whole, An Introduction to Islamic Economics is an interesting general reading. Parts of it can also be of value to students. However, professional economists might see the work more as a horizontal collection of ideas than a vertical movement of thought. And evidently, Akram's borrowings are too many for a fuller referencing.

Zubair Hasan

Department of Economics

International Islamic University, Malaysia

Selangor, Darul Ehsan, Malaysia 